\title{
Macroeconomic, institutional and financial determinants of current account balances: a panel data assessment
}

\author{
Yasin Baris Altayligil ${ }^{1}$ and Murat Çetrez $2^{*^{*}}$ (D)
}

\author{
${ }^{*}$ Correspondence: \\ mcetrez@ford.com.tr \\ ${ }^{2}$ Ford Otomotiv Sanayi A.S.., \\ Istanbul PC 34885, Turkey \\ Full list of author information \\ is available at the end of the \\ article
}

\begin{abstract}
This study aims to find out the fundamental macroeconomic, institutional and financial determinants of current account balances by using panel data analysis method. The analysis is carried out by using the data for the period between 1986 and 2013 of 97 developing and developed countries. We find that the determinants of current account balances can be related to the factors such as fiscal balance, growth, terms of trade, exchange rate, trade openness, stage of economic development, oil dependency, financial market development, macroeconomic stability and institutional quality. A rise in growth rate, real effective exchange rate, fiscal deficit, trade openness, institutional quality, financial market development and stage of development generates larger current account deficits. A rise in terms of trade, inflation rate (representing macroeconomic stability), crude oil export reduces the current account deficits. For industrial countries, macroeconomic stability and growth also have the opposite effect on current account balances compared with other groups. The legal system and property rights, voice and accountability, political stability and absence of violence, political risks are identified as the institutional determinants of current account balances.
\end{abstract}

Keywords: Current account balances, Macroeconomic stability, Institutions, Financial development, Panel data

JEL Classification: F14, C33, G20, K11

\section{Introduction}

After late-1990s current account positions of the major economies have started to change. Global imbalances began to widen to exceed 5\% of GDP in 2008 from 2\% in 1996. The most significant change was widening in the current account deficit of the USA from less than $2 \%$ of GDP in 1997 to $5.8 \%$ in 2006. The USA has started to run a current account deficit since 1992. In Europe, the UK, France, Italy, Poland and Greece are some of the countries have run current account deficits for some years during that period. Germany has run current account surplus between 2002 and 2014. In Far East Asia, Japan has run current account surplus between 1981 and 2013. The highest surplus in Japan was 4.9\% in 2007. Similarly South Korea, Malaysia and Singapore have run current account surplus since 1998. China has run 20 years of surplus since 1994. In Far East

(c) The Author(s) 2020. This article is licensed under a Creative Commons Attribution 4.0 International License, which permits use, sharing adaptation, distribution and reproduction in any medium or format, as long as you give appropriate credit to the original author(s) and the source, provide a link to the Creative Commons licence, and indicate if changes were made. The images or other third party material in this article are included in the article's Creative Commons licence, unless indicated otherwise in a credit line to the material. If material is not included in the article's Creative Commons licence and your intended use is not permitted by statutory regulation or exceeds the permitted use, you will need to obtain permission directly from the copyright holder. To view a copy of this licence, visit http://creativeco mmons.org/licenses/by/4.0/. 
Asia there is a significant amount of surplus during that period. In Latin America, Brazil has run a deficit between 2008 and 2014. Mexico has current account deficits since 1988.

Escalating world oil prices may have also contributed to a change in the distribution of current account balances. For instance, crude oil price was around 16 dollars per barrel in 1994, in 2012 it increased to 112 dollars per barrel. Oil exporter developing countries have benefited from this price increment. As a result, the trade balance of some of these developing countries has increased significantly. This had a significant effect on the surpluses of oil-exporting countries. World surpluses have been distributed across five major locations since 2002 to until 2014: Germany, Japan, China, emerging Far East Asia and oil-exporting countries. Bernanke (2005) saving glut hypothesis argues the pattern of global imbalances in the 2000s reflect in part the flow of financial capital from emerging economies with under-developed institutions and financial markets and excess savings towards economies perceived to have more efficient institutions and financial systems like the USA.

In the literature, several studies have examined the determinants of current account balances until now. The first group of studies have worked on the response of current account imbalances to shocks in just one specific determinant. The second group of studies have tried to identify the macroeconomic medium-term determinants of current account using panel data analysis. The last group of studies have tried to identify the institutional and financial determinants as well as macroeconomic determinants of the current account balances for different groups of developed and developing countries. Debelle et al. (1996), Freund (2000), Calderon et al. (2002), Chinn and Prasad (2003), Aristovnik (2006), Chinn and Ito (2007), Legg et al. (2011), Gruber and Kamin (2009) and Cheung et al. (2013) are some of the studies on the determinants of current account balances. There are different results about the effect of financial development in literature it is required to understand the effect better with extended time period after the financial crisis. It is also important to understand if there are new institutional determinants of current account balances with the extended time period. So a large number of institutional variables and macroeconomic stability variable are added to the study. This paper contributes and extends previous empirical studies by:

- One of the most comprehensive studies in terms of time period and the number of countries in the literature. The analysis is carried for 97 developing and developed countries in six different country groups for 28 years which also includes the time period after the 2008 financial crisis which most of the other papers do not capture. This helped to understand for each country group which factors are more important. All the countries with large contributions to global imbalances are added.

- Investigating the largest number of institutional factors in the longest time period related with the legal system, political system, political risks and stability, corruption behind current account balances for a panel of developed and developing countries which are identified by Bernanke (2005). New determinants, such as legal system and property rights, voice and accountability, political stability and absence of violence, political constraints which are represented with indexes, are identified. These factors are found to have negative and statistically significant relations for some of the country groups. 
Cheung et al. (2013) find a statistically significant relationship only with regularity quality and current account balance with a negative sign for the full sample. They were not able to find any relationship with political risks, voice and accountability, political stability, government effectiveness, rule of law, control of corruption and political constraint variables. Chinn and Ito (2007) find a statistically significant relationship with legal variable which is combined of law and order, corruption and bureaucracy quality. Gruber and Kamin (2005) find a statistically significant relationship only with regulatory quality and rule of law for some of the country groups. They were not able to find any relationship individually with voice and accountability, political stability, government effectiveness and controls of corruption.

Voice and accountability, political stability and absence of violence, political constraint variables are tested individually and identified as institutional determinants of current account balances in a study for the first time. Although some legal systemrelated variables were found as determinants of current account balances in other studies, legal system and property rights variable is found as one of the determinants of current account balances for the first time in this study. It is not about the general quality of a country's complete legal system, but measures specifically the degree to which a country's legal system protects private property rights and to which its government enforces those laws.

- Extending the set of factors.For the first time, inflation rate (CPI) representing macroeconomic stability (in the form of low inflation) factor which is identified by Bernanke (2005), is added to the study. Macroeconomic stability is found to have positive and statistically significant relations with current account balances for three country groups. One of the macroeconomic factors, net average crude oil export per GDP is used in the analysis to measure the direct effect of oil dependency instead of production or consumption. It is found to have positive and statistically significant relations with current account balances for five groups of countries.

- Financial market development (as measured by the share of private credit to GDP) is found to have overall negative and statistically significant relationships with current account balances for all country groups without exception for the first time in a study. Gruber and Kamin (2009) are unable to find consistently statistically significant impact with current account balance and financial development as measured by the share of private credit to GDP. They reach a conclusion that different quantity of measures of financial development including private credit neither appears to influence current account balances in the expected direction nor did they help explain the large developing country surpluses or the outsized US deficit. Legg et al. (2011) are unable to find statistically a significant relationship with current account balance and stock market turnover (financial deepness). Cheung et al. (2013) find a statistically significant impact with current account balance only for the full sample.

For the rest of the article, Sect. 2 discusses the potential factors behind the external balances, Sect. 3 describes the data and methodology, Sect. 4 presents the results, and Sect. 5 gives the conclusions. 


\section{Assessing the factors of global current account balances}

The factors considered in the empirical analysis are described in this section. For the selection of the variables, the study of Cheung et al. (2013) is considered. Macroeconomic stability variable, net crude oil export variable, real effective exchange rate, terms of trade and further institutional variables are also added. Data sources for these factors are given in Table 1.

Country list: high income: Argentina, Australia, Austria, Belgium, Canada, Chile, Croatia, Czech Republic, Denmark, Estonia, Finland, France, Germany, Greece, Hungary, Iceland, Ireland, Israel, Italy, Japan, S. Korea, Latvia, Lithuanian, Luxembourg, Holland, N. Zealand, Norway, Poland, Portugal, Russia, Singapore, Slovakia, Slovenia, Spain, Swiss, Switzerland, United Kingdom, USA, Uruguay, Venezuela, Cyprus, Hong Kong, Macao, Malta. Developing: Afghanistan, Albania, Algeria, Angola,

Table 1 Source of the data

\begin{tabular}{|c|c|c|c|}
\hline & Variables & $\begin{array}{l}\text { Number } \\
\text { of observations }\end{array}$ & Data source \\
\hline \multicolumn{4}{|c|}{ Dependent variables } \\
\hline 1 & Current account/GDP (\%) & 2936 & WEO \\
\hline \multicolumn{4}{|c|}{ Macroeconomic determinants } \\
\hline 2 & GDP (\%) & 3111 & World Bank \\
\hline 3 & Terms of trade & 2363 & World Bank \\
\hline 4 & Real effective exchange rate & 3132 & Bruegel Think Tank \\
\hline 5 & Trade openness $(X+M) / G D P(\%)$ & 3079 & World Bank \\
\hline 6 & Average net crude oil export/GDP (\%) & 2457 & EIA, World Bank \\
\hline 7 & Government expenditures/GDP (\%) & 3062 & World Bank \\
\hline 8 & Fiscal balance/GDP (\%) & 2012 & World Bank, OECD \\
\hline 9 & Relative income $(U S=1)$ & 3139 & World Bank \\
\hline \multicolumn{4}{|c|}{ Demographics determinants } \\
\hline 10 & Old-age dependency ratio (\%) & 3385 & World Bank \\
\hline 11 & Youth dependency ratio (\%) & 3385 & World Bank \\
\hline \multicolumn{4}{|c|}{ Macroeconomic stability determinant } \\
\hline 12 & Inflation rate (CPI) & 3031 & WEO \\
\hline \multicolumn{4}{|c|}{ Financial determinants } \\
\hline 13 & Total private credit/GDP (\%) & 2945 & World Bank \\
\hline 14 & Stock market capitalization/GDP (\%) & 1984 & World Bank \\
\hline 15 & Market turnover/GDP (\%) & 1957 & World Bank \\
\hline \multicolumn{4}{|c|}{ Institutional determinants } \\
\hline 16 & Legal system and property rights index & 1493 & Fraser Institute \\
\hline 17 & Regulation index & 1492 & Fraser Institute \\
\hline 18 & Political constraint (Polcon V) index & 2942 & POLCON \\
\hline 19 & Voice and accountability index & 1536 & World Bank \\
\hline 20 & Control of corruption index & 1552 & World Bank \\
\hline 21 & Political stability and absence of violence index & 1552 & World Bank \\
\hline 22 & Regulatory quality index & 1552 & World Bank \\
\hline 23 & Rule of law index & 1552 & World Bank \\
\hline 24 & Economic freedom summary index & 1492 & Fraser Institute \\
\hline
\end{tabular}


Armenia, Azerbaijan, Bangladesh, Bolivia, Botswana, Brazil, Bulgaria, Cameroon, Chad, China, Democratic Republic of Congo, Egypt, Ethiopia, Fiji, Gabon, Georgia, Ghana, Guatemala, Haiti, Honduras, India, Indonesia, Iran, Jordan, Kazakhstan, Kenya, Kirghizsthan, Macedonia, Madagascar, Malaysia, Mexico, Morocco, Mozambique, Nepal, Nicaragua, Pakistan, Paraguay, Peru, Philippines, Romania, Republic of South Africa, Serbia, Sudan, Thailand, Tunisia, Turkey, Uganda, Ukraine, Zimbabwe.

- Real effective exchange rate Changes in the real effective exchange rate will affect the prices of the import and export goods with the country's currency. Goods will be relatively more expensive or cheaper which have a positive or negative impact on the current account balances. The Marshall Lerner condition states that depreciation or devaluation of the exchange rate will eventually lead to a net improvement in the trade balance provided that the sum of the price elasticity of demand for exports and imports are greater than 1 . So a negative relationship is expected between the real effective exchange rate and current account balances. Many countries are still using fixed or managed floating exchange rate regimes. Some countries (such as China) have undervalued their exchange rate to increase the amount of export to promote growth. European Union countries since they all use the same currency, and they do not individually have control over the value of the Euro. When the euro is overvalued especially developing countries of EU could suffer on current account balances. Legg et al. (2011) add real effective exchange rate into their analyses and see that model appears to improve for several regions for particular periods. Cheung et al. (2013) find that the real effective exchange rate is one of the cyclical factors part of the narrowing the current account balances. Aristovnik (2006) finds an appreciation of the real exchange rate deteriorates the current account deficit.

- Terms of trade This is the ratio of export to import prices. Only the prices of tradeable goods are included in terms of trade. Changes in terms of trade will affect the amount of national savings and will have a positive or negative impact on the current account balance of a country. There are many fluctuations in small open economies because small economies can be easily disturbed by external shocks through international trade. Harberger (1950), Laursen and Metzler (1950) suggests that a reduction in current income arising from a terms of trade shock would decrease both private savings and the current account balance. Meeting the conditions of Harberger, Laursen and Metzler effect means income effect caused by the terms of trade degradation will reduce current income and total savings and this will eventually cause the deterioration of the current account balance. Developing countries which are unable to produce and export high technology goods expected to run higher current account deficits. Debelle et al. (1996) find that terms of trade have short-run effects on the current account balance. Aristovnik (2006) finds that worsening terms of trade generate a deterioration of the current account deficit.

- Demographics Demographic variation may be an important factor in national savings which may explain the differences in current accounts across countries. The life-cycle hypothesis suggests that the saving behaviour of households varies with age. As a result, countries with a relatively high percentage of young and elderly 
households would tend to run current account deficits. So based on the life-cycle hypothesis negative relationship is expected between demographic variables and current account balances. The main variables tested include youth and old-age dependency ratios. Legg et al. (2011) find that demographic factors have a significant impact on a nation's current account balance.

- Fiscal balance A rise in the public deficit can reduce national savings without a Ricardian offset from private savings and may increase current account deficits. A positive relationship is expected. In most of the studies, a positive relationship between fiscal balances and current account balances has been found. Also the effect of budget deficits on current account balances may be related with how fiscal expenditures are allocated. Chinn and Prasad (2003) find that the current account balances are positively correlated with government budget balances.

- Stage of economic development Standard neoclassical theory suggests that developing countries with low capital-labour ratios will import capital from developed countries and run current account deficits. The stages of development hypothesis suggest that countries when they reach an intermediate stage of development from a low stage of development, they begin to import capital and run current account deficits. As they become a more developed economy, countries start to run current account surpluses to pay off external debts. Eventually, they begin to export capital to developing economies. In the years before the global financial crisis, the opposite pattern has been observed for capital flows. Lucas (1988) explains that capital flows to developing countries have been less than expected because of domestic distortions that lower the risk-adjusted returns to capital. These distortions may be related with under-developed financial markets or weak institutions, and this may explain why financial capital tends to flow to developed countries instead of developing countries. A negative or positive relationship can be expected based on the validity of the neoclassical theory or Lucas (1988) paradox. Negative relationship supports Lucas Paradox. Positive relationship supports the neoclassical theory. The variable used to represent the stage of economic development is the relative $(U S A=1)$ income per capita. Cheung et al. (2013) find the stage of development as one of the structural factors of current accounts.

- Level of financial development A common explanation for widening current account balances is that some of the developing countries have exported their excess capital to countries with more developed financial markets (Ju and Wei 2006). Moreover, the financial development could also encourage consumption and decrease the saving rates. If these explanations are true, improved financial deepening could reduce saving rates in these economies, and could cause a negative relationship between financial development and current account balances. An alternative opposite effect can be considered. Generally, financial market development has been considered to encourage savings by reducing transaction costs and facilitating risk management. This will cause a positive effect on the saving rates and also on the current account. Empirical results are mixed, and it depends on the set of countries and variables that are used to proxy financial deepness. The variables tested are (i) private credit as a 
share of GDP; (ii) stock market capitalization as a share of GDP; (iii) stock market turnover as a share of GDP.

- Quality of institutions Bernanke (2005) suggests to help developing countries to re-enter international capital markets as borrowers instead of lenders. Developing countries could improve their investment climates by continuing to raise macroeconomic stability, decrease corruption, strengthen property rights, and allow the flow of financial capital. One of the explanations for Lucas paradox of capital flowing to developed countries instead of developing countries is, weak institutions decrease the risk-adjusted return to capital in developing countries (Alfaro et al. 2005). So when the quality of institutions and macroeconomic stability are improved, current account deficits will increase. So based on that negative relationship is expected between the quality of institutions and current account balances, nine variables for the quality of institutions are added to the study.

- Macroeconomic stability Bernanke (2005) suggests that developing countries improve their investment climate by continuing to increase macroeconomic stability. CPI is added to this study. If inflation is low more financial capital out of the country will enter the country which will cause to increase the current balance deficit. Odedokun (2003) finds in his study, a stable macroeconomic environment in the form of low inflation and low monetary expansion is an important determinant for attracting foreign private capital to developing countries for the investors in a capital-exporting country. So a positive relationship is expected between macroeconomic stability and current account balances for developing countries.

- Oil dependency On the current account balance, it is important if a country is a net exporter or a net importer of crude oil. The impact on current account balances would then change with how much a country uses oil in its economy as an importer, or with the relative importance of oil production in its economy as an exporter. The variable used to indicate a country's oil intensity or dependency is the net average crude oil export per GDP. Several variables were used until now, but the average crude oil export variable is the most direct way to measure the dependency. A positive relationship is expected between average net crude oil and current account balances. Cheung et al. (2013) find that oil dependency and intensity is one of the structural factors of current account balances.

- Growth Countries with high labour productivity growth may attract foreign capital flows because they are expected to produce higher rates of return. Also when emerging countries grow faster, it will cause more intermediate goods and machinery investment import which will cause higher current balance deficits. This higher current balance deficit means a negative relationship between growth and current account balances. For developed countries, the opposite may be expected to happen. With higher growth rates they may export more high technology goods which will have a positive effect on current account balances. The real GDP growth rate is used in the study. Calderon et al. (2002) find that a rise in domestic output growth generates larger current account deficits.

- Trade openness Widening current account positions could result in part from increasing globalization, which increases cross-border trade and financial capital flows. A country's degree of openness to international trade, measured as total 
exports and imports as a share of GDP, could also reflect industrial policy choices, including tariff regimes. Developing countries which are highly open to international trade may run higher current account deficits since they have to import a lot of intermediate goods and machinery from developed countries. The negative relationship can be expected for most of the developing countries. Chinn and Prasad (2003) find that trade openness is negatively correlated with current account balances.

\section{Data and methodology}

This study aims to find out the fundamental macroeconomic, institutional and financial determinants of current account balances by using panel data analysis method. The analysis is carried out by using the data for the period between 1986 and 2013 (includes the time period after 2008 financial crisis) of 97 developing and developed countries.

\subsection{Data and model}

The sample covers 97 countries ( 44 high income and 53 developing countries based on IMF categories) for the period of 1986-2013. Growth rate, terms of trade, real effective exchange rate, trade openness, average net crude oil export, government expenditures, fiscal balance, relative income are the macroeconomic variables that are used in the study. These variables are collected from World Bank (2016a), OECD (2016), US Energy Information Administration (2016) and Bruegel (2016) economic think tank databases. Macroeconomic variables are added in the study starting from 1986.

Old-age dependency ratio and youth dependency ratio are the demographics variables that are used in the study. They are collected from World Bank (2016a) database. Inflation rate $(\mathrm{CPI})$ is the only macroeconomic stability variable that is used in the study. Data are collected from World Economic Outlook (2016). Total private credit, stock market capitalization and market turnover are the financial variables that are used in the study. Data are collected from the World Bank (2016a).

Nine institutional variables are used in the study. These are legal system and property rights index, regulation index, political constrain index, voice and accountability index, control of corruption index, political stability and absence of violence index, regularity quality index, rule of law index and economic freedom index. Variables are collected from Fraser Institute (2017), World Bank (2016b) and Wharton Management Faculty (2016). Some of the institutional variables like economic freedom index, legal system and property rights index, regulation index are available from 1990. Voice and accountability, political stability and absence of violence, regulatory quality and rule of law institutional variables are available from 1996.

To identify the determinants of current account balances, they are regressed on to a set of macroeconomic, financial and institutional variables. First baseline results are found out based on the regression of macroeconomic factors. Then institutional and financial factors are added to the study. Chinn and Ito (2007), Cheung et al. (2013) and Gruber and Kamin (2009) have the same approach. We estimate:

$$
\begin{aligned}
\text { Current account balances }= & \text { macroeconomic variables }+ \text { financial variables } \\
& + \text { macroeconomic stability variables or institutional variables }
\end{aligned}
$$




$$
\mathrm{CA}_{\mathrm{it}}=\alpha_{\mathrm{it}}+\beta X_{\mathrm{it}}+\mu F_{\mathrm{it}}+\theta I_{\mathrm{it}}+u_{\mathrm{it}}
$$

where CA is the current account balances, $X$ is a vector of macroeconomic variables, $F$ is a vector of financial indicators, and $I$ is a set of macroeconomic stability or institutional variables.

\subsection{Econometric methodology}

Panel data analysis method is used to find out the fundamental macroeconomic, institutional and financial determinants of current account balances. Our model comprises annual data to be able to capture more details and changes. Legg et al. (2011) also used annual data in their analysis. The panel data set is not balanced. It means that for some of the variables the length of the series varies by country because of missing data. These steps are followed in the study.

Numerous time panel datasets show considerable cross-sectional dependence that may arise due to the presence of common shocks and unobserved components (Hoyos and Sarafidis 2006). Paseran test (2004) is used to identify the cross-sectional dependence of the variables. First-generation unit root tests do not consider the cross-sectional dependency. It is observed most of the time that there is a cross-sectional dependency among the variables. It was decided to use second-generation root tests when there is cross-sectional dependency. So both second-generation Pesaran (2007) and first-generation Fisher (Choi 2001) panel root tests are applied based on cross-sectional dependence test results.

Based on Pesaran (2007) and Fisher (Choi 2001) unit root test results, the first differences of the variables are decided to be used. It is observed that most of the time variables are not stationary. But instead the first differences of all the variables are always stationary. Pooled least squares models are used based on F and Hausman (1978) tests' results. Autocorrelation and heteroscedasticity are also checked by using White (1980) and Wooldridge (2002) tests. When autocorrelation and heteroscedasticity are observed, pooled least squares models are fixed by Huber (1967), Eicker (1967) and White (1980) or Arellano (1987), Froot (1989) and Rogers (1994) estimators.

\section{Results}

Estimation results for the baseline specification are shown in Table 2. The last column reports the results when all countries are included in the estimation. Six different groups of countries are included in the study. Because of the large degree of heterogeneity across the diverse set of countries, columns between (2) to (6) compare results when the sample is restricted to industrialized, high-income, developing, full sample, the full sample without industrialized and full sample without African and industrialized countries. In literature generally, 22 countries are considered as industrial countries: Australia, Austria, Belgium, Canada, Denmark, Finland, France, Germany, Greece, Iceland, Ireland, Italy, Japan, Holland, New Zealand, Norway, Portugal, Spain, Sweden, Swiss, UK, USA. The same approach is used in this study. 
Table 2 Current account balance: baseline specifications (1986-2013)

\begin{tabular}{|c|c|c|c|c|c|c|}
\hline & Industrial & High income & Developing & $\begin{array}{l}\text { Full sample - } \\
\text { Industrial }\end{array}$ & $\begin{array}{l}\text { Full sample - } \\
\text { Africa } \\
\text { and Industrial }\end{array}$ & Full sample \\
\hline GDP & $\begin{array}{l}.1631 \\
(2.27)^{* *}\end{array}$ & $\begin{array}{l}-.1152 \\
(-2.19)^{* *}\end{array}$ & $\begin{array}{l}.0043 \\
(.07)\end{array}$ & $\begin{array}{l}-.0883 \\
(-1.69)^{*}\end{array}$ & $\begin{array}{l}-.1259 \\
(-1.81)^{*}\end{array}$ & $\begin{array}{l}-.0653 \\
(-1.36)\end{array}$ \\
\hline Fiscal balance/GDP & $\begin{array}{l}.0111 \\
(.07)\end{array}$ & $\begin{array}{l}.1766 \\
(1.52)\end{array}$ & $\begin{array}{l}.3302 \\
(3.39)^{* * *}\end{array}$ & $\begin{array}{l}.3394 \\
(3.59)^{* * *}\end{array}$ & $\begin{array}{l}.1763 \\
(1.92)^{*}\end{array}$ & $\begin{array}{l}.3197 \\
(3.68)^{* * *}\end{array}$ \\
\hline Terms of trade & $\begin{array}{l}.0549 \\
(1.72)^{*}\end{array}$ & $\begin{array}{l}.0244 \\
(1.60)\end{array}$ & $\begin{array}{l}.1118 \\
(5.47)^{* * *}\end{array}$ & $\begin{array}{l}.0818 \\
(4.73)^{* * *}\end{array}$ & $\begin{array}{l}.0576 \\
(2.58)^{* *}\end{array}$ & $\begin{array}{l}.0793 \\
(4.85)^{* * *}\end{array}$ \\
\hline $\begin{array}{l}\text { Real effective } \\
\text { exchange rate }\end{array}$ & $\begin{array}{l}-.0669 \\
(-1.47)\end{array}$ & $\begin{array}{l}-.0502 \\
(-2.98)^{* * *}\end{array}$ & $\begin{array}{l}-.1345 \\
(-4.00)^{* * *}\end{array}$ & $\begin{array}{l}-.1057 \\
(-4.26)^{* * *}\end{array}$ & $\begin{array}{l}-.1028 \\
(-3.48)^{* * *}\end{array}$ & $\begin{array}{l}-.1049 \\
(-4.49)^{* * *}\end{array}$ \\
\hline Trade openness & $\begin{array}{l}-.0410 \\
(-.90)\end{array}$ & $\begin{array}{l}-.0085 \\
(-.42)\end{array}$ & $\begin{array}{l}-.1789 \\
(-5.00)^{* * *}\end{array}$ & $\begin{array}{l}-.0921 \\
(-3.70)^{* * *}\end{array}$ & $\begin{array}{l}-.0584 \\
(-2.32)^{* *}\end{array}$ & $\begin{array}{l}-.0884 \\
(-3.77)^{* * *}\end{array}$ \\
\hline Relative income & $\begin{array}{l}-27.9918 \\
(-2.34)^{* *}\end{array}$ & $\begin{array}{l}-18.6167 \\
(-2.03)^{* *}\end{array}$ & $\begin{array}{l}-187.4111 \\
(-2.88)^{* * *}\end{array}$ & $\begin{array}{l}-17.9461 \\
(-1.15)\end{array}$ & $\begin{array}{l}-16.0701 \\
(-.82)\end{array}$ & $\begin{array}{l}-17.1117 \\
(1.68)^{*}\end{array}$ \\
\hline $\begin{array}{l}\text { Average net crude } \\
\text { oil export/GDP }\end{array}$ & $\begin{array}{l}.4006 \\
(1.28)\end{array}$ & $\begin{array}{l}.6631 \\
(3.08)^{* * *}\end{array}$ & $\begin{array}{l}.6314 \\
(4.43)^{* * *}\end{array}$ & $\begin{array}{l}.6580 \\
(4.61)^{* * *}\end{array}$ & $\begin{array}{l}.8318 \\
(3.75)^{* * *}\end{array}$ & $\begin{array}{l}.6543 \\
(4.65)^{* * *}\end{array}$ \\
\hline R-sq & .0913 & .1335 & .3319 & .2720 & .1999 & .2540 \\
\hline $\begin{array}{l}\text { Number of obser- } \\
\text { vations }\end{array}$ & 285 & 529 & 754 & 997 & 761 & 1282 \\
\hline
\end{tabular}

All variables are used in their first differences. $t$-statistics in parenthesis. ${ }^{*}, * *, * * *$ indicate significance level at $10 \%, 5 \%, 1 \%$, respectively. The estimates for the constants are not shown

\subsection{Baseline specification: macroeconomic determinants}

The growth rate is one of the determinants of the current account balance (impact is statistically significant) except developing countries and all countries group. There is a negative relationship between growth and current account balances. An increase in the growth rate leads to an increase in the current account deficit for those countries. One percentage increase in growth rate is associated with a .12\% increase in the current account deficit in first differences for full sample except for industrial and African countries. So this supports, countries with high labour productivity growth may attract foreign capital flows because they are expected to produce higher rates of return. Also when emerging countries grow faster, it will cause more intermediate goods and machinery investment import which will cause higher current account balance deficits. In other words, investment and consumption expenditures increase with higher growth rates. And when consumption increases, current account deficit increases too.

For industrial countries, there is a positive relationship between growth rate and current account balances. This explains that production for export supports the growth. This supports with higher growth they export more high technology goods which will have a positive effect on current account balances. One percentage increase in growth rate is associated with a $.16 \%$ increase in current account surplus in first differences.

Fiscal balance appears to be another determinant of the current account balance except for industrial and high-income countries. As expected there is a positive relationship between fiscal balance and current account balance. This means, an increase in the public deficit lower national savings. It also shows that an increase in the fiscal deficits 
has the effect of expanding total consumption and current account deficits. Overall, $1 \%$ increase in the fiscal deficit is associated with a . $3 \%$ increase in the current account deficit in first differences for the full sample.

Terms of trade are one of the determinants of the current account balance for all groups. There is a positive relationship. Results support changes in terms of trade will affect the amount of national savings. Current account deficit gets lower when terms of trade increase. One percentage growth in terms of trade is estimated to increase a nation's current account balance by around .12\% in first differences for developing countries. Results support, Laursen and Metzler (1950) saying that a reduction in current income arising from a terms of trade shock would decrease both private savings and the current account balance. Income effect caused by the terms of trade degradation will reduce current income and total savings and this will eventually cause the deterioration of the current account.

REER is another determinant of the current account balance for all groups except industrial countries. REER has a negative sign as expected. An increase in REER leads to an increase in the current account deficit. Results support the Marshall Lerner condition, states that a depreciation or devaluation of the exchange rate will eventually lead to a net improvement in the trade balance that the sum of the price elasticity of demand for exports and imports are greater than 1 .

Countries more open to trade tend to run higher current account deficits, although this factor is insignificant for industrial and high-income countries. There is a negative relationship. Results support developing countries which are highly open to international trade run higher current account deficits. They may have to import a lot of intermediate goods and machinery from developed countries.

There is a statistically significant negative relationship between the stage of economic development and current accounts balance except for two groups. When the stage of economic development increases current account deficit increases as well. These results support Lucas Paradox for these country groups. Lucas (1988) explains that capital flows to developing countries have been lower than expected because of domestic distortions that lower the risk-adjusted returns to capital. These distortions may include underdeveloped financial markets or weak institutions, and this may explain why financial capital tends to flow to the developed countries instead of the developing countries.

As expected countries with important crude oil export tend to have higher current account balances, this relation is insignificant only for industrial countries. Oil prices continuously increased especially after 2000 , so crude oil export becomes a significant factor for current account balances. Crude Brent oil price was around 16 dollars per barrel in 1994 in 2012 price increased to 112 dollars per barrel. One percentage increase in crude oil export is associated with $.65 \%$ increase in current account surplus in first differences for the full sample.

\subsection{The role of financial development, macroeconomic stability and institutional quality}

Among the institutional variables tested, financial market development, inflation rate representing macroeconomic stability, political risks (Polcon V), political stability, legal 
system and property rights and voice and accountability have statistically significant relationships with current account balances for some group of countries.

Political constraint index (Polcon V) is a measurement of the feasibility of change in policy given the structure of a country's political institutions and the preference of the actors that inhabit them. It is developed for political risk analysis for investment purposes and for predicting policy variability more generally. Voice and accountability index is a measurement of which a nation's citizens can vote to select their government, as well as the level of expression freedom, level of association freedom, and free media.

Political stability and absence of violence index are about the perceptions of the likelihood that the government will be destabilized or overthrown by unconstitutional or violent means, including political violence or terrorism. The legal system and property right index measures the ability of protection of persons and their rightfully acquired property, secured by clear laws that are fully enforced by the state and government. So it is a measurement of the degree to which a country's legal system and laws protect private property rights and the degree to which its government enforces those laws.

Financial market development (as measured by the share of private credit to GDP) is found to have overall negative and statistically significant relationships with current account balances for all country groups for the first time in a study (Table 3). A negative relationship is consistent with the findings of Kennedy and Slok (2005), Gruber and Kamin (2009) and Cheung et al. (2013). Gruber and Kamin (2009) are unable to find

Table 3 Current account balance: financial development (1986-2013)

\begin{tabular}{|c|c|c|c|c|c|c|}
\hline & Industrial & High income & Developing & $\begin{array}{l}\text { Full sample - } \\
\text { Industrial }\end{array}$ & $\begin{array}{l}\text { Full sample - } \\
\text { Africa } \\
\text { and Industrial }\end{array}$ & Full sample \\
\hline GDP & $\begin{array}{l}.1515 \\
(1.95)^{*}\end{array}$ & $\begin{array}{l}-.0682 \\
(-1.48)\end{array}$ & $\begin{array}{l}-.0088 \\
(-.13)\end{array}$ & $\begin{array}{l}-.0796 \\
(-1.50)\end{array}$ & $\begin{array}{l}-.1111 \\
(-1.59)\end{array}$ & $\begin{array}{l}-.0582 \\
(-1.19)\end{array}$ \\
\hline Fiscal balance & $\begin{array}{l}-.0195 \\
(-.12)\end{array}$ & $\begin{array}{l}.1070 \\
(.96)\end{array}$ & $\begin{array}{l}3179 \\
(3.32)^{* * *}\end{array}$ & $\begin{array}{l}3212 \\
(3.45)^{* * *}\end{array}$ & $\begin{array}{l}.1390 \\
(1.53)\end{array}$ & $\begin{array}{l}.3043 \\
(3.53)^{* * *}\end{array}$ \\
\hline Terms of trade & $\begin{array}{l}.0448 \\
(1.29)\end{array}$ & $\begin{array}{l}.0156 \\
(1.02)\end{array}$ & $\begin{array}{l}.1082 \\
(5.29)^{* * *}\end{array}$ & $\begin{array}{l}.0798 \\
(4.61)^{* * *}\end{array}$ & $\begin{array}{l}.0574 \\
(2.57)^{* *}\end{array}$ & $\begin{array}{l}.0764 \\
(4.60)^{* * *}\end{array}$ \\
\hline $\begin{array}{l}\text { Real effective } \\
\text { exchange rate }\end{array}$ & $\begin{array}{l}-.0697 \\
(-1.50)\end{array}$ & $\begin{array}{l}-.0625 \\
(-3.66)^{* * *}\end{array}$ & $\begin{array}{l}-.1310 \\
(-3.79)^{* * *}\end{array}$ & $\begin{array}{l}-.1086 \\
(-4.36)^{* * *}\end{array}$ & $\begin{array}{l}-.1102 \\
(-3.78)^{* * *}\end{array}$ & $\begin{array}{l}-.1075 \\
(-4.57)^{* * *}\end{array}$ \\
\hline Trade openness & $\begin{array}{l}-.0649 \\
(-1.37)\end{array}$ & $\begin{array}{l}-.0155 \\
(-.74)\end{array}$ & $\begin{array}{l}-.1762 \\
(-4.92)^{* * *}\end{array}$ & $\begin{array}{l}-.0926 \\
(-3.70)^{* * *}\end{array}$ & $\begin{array}{l}-.0588 \\
(-2.34)^{* *}\end{array}$ & $\begin{array}{l}-.0893 \\
(-3.78)^{* * *}\end{array}$ \\
\hline Relative income & $\begin{array}{l}-25.2878 \\
(-1.98)^{* *}\end{array}$ & $\begin{array}{l}-15.5177 \\
(-1.67)^{*}\end{array}$ & $\begin{array}{l}-177.0909 \\
(-2.72)^{* * *}\end{array}$ & $\begin{array}{l}-11.7724 \\
(-.78)\end{array}$ & $\begin{array}{l}-8.7412 \\
(-.49)\end{array}$ & $\begin{array}{l}-12.9486 \\
(-1.25)\end{array}$ \\
\hline $\begin{array}{l}\text { Average net crude } \\
\text { oil }\end{array}$ & .0648 & .5471 & .6198 & 6493 & .8169 & .6431 \\
\hline Export/GDP & $(.18)$ & $(2.58)^{* * *}$ & $(4.31)^{* * *}$ & $(4.52)^{* * *}$ & $(3.55)^{* * *}$ & $(4.53)^{* * *}$ \\
\hline $\begin{array}{l}\text { Total private credit/ } \\
\text { GDP }\end{array}$ & $\begin{array}{l}-.0360 \\
(-2.96)^{* * *}\end{array}$ & $\begin{array}{l}-.0247 \\
(-3.88)^{* * *}\end{array}$ & $\begin{array}{l}-.0556 \\
(-2.01)^{* *}\end{array}$ & $\begin{array}{l}-.0303 \\
(-2.92)^{* * *}\end{array}$ & $\begin{array}{l}-.0240 \\
(-2.67)^{* * *}\end{array}$ & $\begin{array}{l}-.0319 \\
(3.84)^{* * *}\end{array}$ \\
\hline$R-s q$ & .1308 & .1324 & .3356 & .2754 & .1994 & .2595 \\
\hline $\begin{array}{l}\text { Number of obser- } \\
\text { vations }\end{array}$ & 259 & 494 & 753 & 987 & 752 & 1246 \\
\hline
\end{tabular}

All variables are used in their first differences. t-statistics in parenthesis. ${ }^{*},{ }^{* *},{ }^{* * *}$ indicate significance at $10 \%, 5 \%, 1 \%$, respectively. The estimates for the constants are not shown 
Table 4 Current account balance: macroeconomic stability (1986-2013)

\begin{tabular}{|c|c|c|c|c|c|c|}
\hline & Industrial & High income & Developing & $\begin{array}{l}\text { Full sample - } \\
\text { Industrial }\end{array}$ & $\begin{array}{l}\text { Full sample - } \\
\text { Africa } \\
\text { and Industrial }\end{array}$ & Full sample \\
\hline GDP & $\begin{array}{l}.1284 \\
(1.84)^{*}\end{array}$ & $\begin{array}{l}-.0717 \\
(-1.75)^{*}\end{array}$ & $\begin{array}{l}-.0047 \\
(-.07)\end{array}$ & $\begin{array}{l}-.0756 \\
(-1.40)\end{array}$ & $\begin{array}{l}-.1202 \\
(-1.82)^{*}\end{array}$ & $\begin{array}{l}-.0544 \\
(-1.09)\end{array}$ \\
\hline Fiscal balance & $\begin{array}{l}-.0563 \\
(-.38)\end{array}$ & $\begin{array}{l}-.2192 \\
(-1.53)\end{array}$ & $\begin{array}{l}.2912 \\
(3.34)^{* * *}\end{array}$ & $\begin{array}{l}.2971 \\
(3.39)^{* * *}\end{array}$ & $\begin{array}{l}.1505 \\
(1.68)^{*}\end{array}$ & $\begin{array}{l}.2810 \\
(3.46)^{* * *}\end{array}$ \\
\hline Terms of trade & $\begin{array}{l}.0560 \\
(1.60)\end{array}$ & $\begin{array}{l}.0261 \\
(1.56)\end{array}$ & $\begin{array}{l}.1011 \\
(5.16)^{* * *}\end{array}$ & $\begin{array}{l}.0738 \\
(4.40)^{* * *}\end{array}$ & $\begin{array}{l}.0578 \\
(2.55)^{* *}\end{array}$ & $\begin{array}{l}.0707 \\
(4.39)^{* * *}\end{array}$ \\
\hline $\begin{array}{l}\text { Real effective exchange } \\
\text { rate }\end{array}$ & $\begin{array}{l}-.0831 \\
(-2.00)^{* *}\end{array}$ & $\begin{array}{l}-.0460 \\
(-2.94)^{* * *}\end{array}$ & $\begin{array}{l}-.1103 \\
(-4.36)^{* * *}\end{array}$ & $\begin{array}{l}-.0932 \\
(-5.04)^{* * *}\end{array}$ & $\begin{array}{l}-.1108 \\
(-3.84)^{* * *}\end{array}$ & $\begin{array}{l}-.0929 \\
(-5.27)^{* * *}\end{array}$ \\
\hline Trade openness & $\begin{array}{l}-.0223 \\
(-.52)\end{array}$ & $\begin{array}{l}.0019 \\
(.10)\end{array}$ & $\begin{array}{l}-.1990 \\
(-5.51)^{* * *}\end{array}$ & $\begin{array}{l}-.1034 \\
(-4.04)^{* * *}\end{array}$ & $\begin{array}{l}-.0542 \\
(-2.29)^{* *}\end{array}$ & $\begin{array}{l}-.0994 \\
(-4.12)^{* * *}\end{array}$ \\
\hline Relative income & $\begin{array}{l}-16.2272 \\
(-1.27)\end{array}$ & $\begin{array}{l}-28.3194 \\
(-2.95)^{* * *}\end{array}$ & $\begin{array}{l}-194.3722 \\
(-3.01)^{* * *}\end{array}$ & $\begin{array}{l}-13.4536 \\
(-.87)\end{array}$ & $\begin{array}{l}-8.0804 \\
(-.46)\end{array}$ & $\begin{array}{l}-14.0832 \\
(-1.34)\end{array}$ \\
\hline $\begin{array}{l}\text { Average net crude oil } \\
\text { export/GDP }\end{array}$ & $\begin{array}{l}-.3252 \\
(-.79)\end{array}$ & $\begin{array}{l}.7246 \\
(4.62)^{* * *}\end{array}$ & $\begin{array}{l}.5610 \\
(4.21)^{* * *}\end{array}$ & $\begin{array}{l}.5876 \\
(4.38)^{* * *}\end{array}$ & $\begin{array}{l}.8262 \\
(3.62)^{* * *}\end{array}$ & $\begin{array}{l}.5805 \\
(4.38)^{* * *}\end{array}$ \\
\hline $\begin{array}{l}\text { Total private credit/ } \\
\text { GDP }\end{array}$ & $\begin{array}{l}-.0315 \\
(-2.73)^{* * *}\end{array}$ & $\begin{array}{l}-.0195 \\
(-3.23)^{* * *}\end{array}$ & $\begin{array}{l}-.0567 \\
(-2.10)^{* *}\end{array}$ & $\begin{array}{l}-.0305 \\
(-2.97)^{* * *}\end{array}$ & $\begin{array}{l}-.0241 \\
(-2.67)^{* * *}\end{array}$ & $\begin{array}{l}-.0323 \\
(-3.90)^{* * *}\end{array}$ \\
\hline Inflation rate (CPI) & $\begin{array}{l}-.4638 \\
(-2.72)^{* * *}\end{array}$ & $\begin{array}{l}.0000 \\
(.11)\end{array}$ & $\begin{array}{l}.0118 \\
(36.42)^{* * *}\end{array}$ & $\begin{array}{l}.0117 \\
(40.45)^{* * *}\end{array}$ & $\begin{array}{l}-.0188 \\
(-.95)\end{array}$ & $\begin{array}{l}.0118 \\
(41.31)^{* * *}\end{array}$ \\
\hline$R-s q$ & .1797 & .2457 & .4385 & .3632 & .2013 & .3428 \\
\hline $\begin{array}{l}\text { Number of observa- } \\
\text { tions }\end{array}$ & 259 & 611 & 744 & 978 & 750 & 1237 \\
\hline
\end{tabular}

All variables are used in their first differences. $t$-statistics in parenthesis. ${ }^{*}, * *, * * *$ indicate significance at $10 \%, 5 \%, 1 \%$, respectively. The estimates for the constants are not shown

consistently statistically significant impact with current account balance and financial development as measured by the share of private credit to GDP. They reach a conclusion that different quantity of measures of financial development including private credit neither appears to influence current account balances in the expected direction nor did they help explain the large developing country surpluses or the outsized US deficit. Legg et al. (2011) are unable to find a statistically significant relationship with current account balance and stock market turnover (financial deepness).

Cheung et al. (2013) find a statistically significant impact with current account balance only for the full sample. Results support financial market development encourage consumption and lower the saving rates instead of increasing the total national savings. Also for some countries, the negative effect may reflect the "by-pass effect" of capital flowing from developing economies towards countries with more efficient institutions or developed financial markets. Additionally, improved financial markets may lower the need for precautionary savings and reduce current account balances.

Odedokun (2003) finds in his study, a stable macroeconomic environment in the form of low inflation and low monetary expansion is an important determinant for attracting foreign private capital to developing countries for the investors in a capital-exporting country. There is a positive relationship between inflation rate and current account 
Table 5 Current account balance: institutional quality-political risks (1986-2013)

\begin{tabular}{|c|c|c|c|c|c|c|}
\hline & Industrial & High income & Developing & $\begin{array}{l}\text { Full sample - } \\
\text { Industrial }\end{array}$ & $\begin{array}{l}\text { Full sample - } \\
\text { Africa } \\
\text { and Industrial }\end{array}$ & Full sample \\
\hline GDP & $\begin{array}{l}.1393 \\
(1.74)^{*}\end{array}$ & $\begin{array}{l}-.0759 \\
(-1.59)\end{array}$ & $\begin{array}{l}.0161 \\
(.31)\end{array}$ & $\begin{array}{l}-.0815 \\
(-1.51)\end{array}$ & $\begin{array}{l}-.1150 \\
(-1.63)\end{array}$ & $\begin{array}{l}-.0603 \\
(-1.21)\end{array}$ \\
\hline Fiscal balance & $\begin{array}{l}-.0441 \\
(-.27)\end{array}$ & $\begin{array}{l}.1202 \\
(1.02)\end{array}$ & $\begin{array}{l}.1990 \\
(2.09)^{* *}\end{array}$ & $\begin{array}{l}.3207 \\
(3.39)^{* * *}\end{array}$ & $\begin{array}{l}.1247 \\
(1.34)\end{array}$ & $\begin{array}{l}.3032 \\
(3.46)^{* * *}\end{array}$ \\
\hline Terms of trade & $\begin{array}{l}.0457 \\
(1.31)\end{array}$ & $\begin{array}{l}.0196 \\
(1.24)\end{array}$ & $\begin{array}{l}.0678 \\
(2.50)^{* *}\end{array}$ & $\begin{array}{l}.0837 \\
(4.81)^{* * *}\end{array}$ & $\begin{array}{l}.0615 \\
(2.76)^{* * *}\end{array}$ & $\begin{array}{l}.0801 \\
(4.79)^{* * *}\end{array}$ \\
\hline $\begin{array}{l}\text { Real effective } \\
\text { exchange rate }\end{array}$ & $\begin{array}{l}-.0751 \\
(-1.37)\end{array}$ & $\begin{array}{l}-.0571 \\
(-2.94)^{* * *}\end{array}$ & $\begin{array}{l}-.1195 \\
(-5.12)^{* * *}\end{array}$ & $\begin{array}{l}-.1083 \\
(-4.25)^{* * *}\end{array}$ & $\begin{array}{l}-.1065 \\
(-3.57)^{* * *}\end{array}$ & $\begin{array}{l}-.1074 \\
(-4.43)^{* * *}\end{array}$ \\
\hline Trade openness & $\begin{array}{l}-.0510 \\
(-1.09)\end{array}$ & $\begin{array}{l}-.0179 \\
(-.71)\end{array}$ & $\begin{array}{l}-.1197 \\
(-3.98)^{* * *}\end{array}$ & $\begin{array}{l}-.1034 \\
(-3.83)^{* * *}\end{array}$ & $\begin{array}{l}-.0682 \\
(-2.33)^{* *}\end{array}$ & $\begin{array}{l}-.0977 \\
(-3.84)^{* * *}\end{array}$ \\
\hline Relative income & $\begin{array}{l}-29.6275 \\
(-2.30)^{* *}\end{array}$ & $\begin{array}{l}-13.6657 \\
(-1.42)\end{array}$ & $\begin{array}{l}-214.1652 \\
(-3.44)^{* * *}\end{array}$ & $\begin{array}{l}-10.7705 \\
(-.68)\end{array}$ & $\begin{array}{l}-6.1277 \\
(-.33)\end{array}$ & $\begin{array}{l}-13.2496 \\
(-1.21)\end{array}$ \\
\hline $\begin{array}{c}\text { Average net crude } \\
\text { oil export/GDP }\end{array}$ & $\begin{array}{l}.1267 \\
(.34)\end{array}$ & $\begin{array}{l}.5266 \\
(2.30)^{* *}\end{array}$ & $\begin{array}{l}.4277 \\
(3.67)^{* * *}\end{array}$ & $\begin{array}{l}.6448 \\
(4.56)^{* * *}\end{array}$ & $\begin{array}{l}.7978 \\
(3.41)^{* * *}\end{array}$ & $\begin{array}{l}.6390 \\
(4.55)^{* * *}\end{array}$ \\
\hline $\begin{array}{l}\text { Total private } \\
\text { credit/GDP }\end{array}$ & $\begin{array}{l}-.0326 \\
(-2.77)^{* * *}\end{array}$ & $\begin{array}{l}-.0208 \\
(-3.66)^{* * *}\end{array}$ & $\begin{array}{l}-.0676 \\
(-2.54)^{* *}\end{array}$ & $\begin{array}{l}-.0277 \\
(-2.88)^{* * *}\end{array}$ & $\begin{array}{l}-.0209 \\
(-2.82)^{* * *}\end{array}$ & $\begin{array}{l}-.0290 \\
(-3.70)^{* * *}\end{array}$ \\
\hline Polcon V & $\begin{array}{l}-.4662 \\
(-.29)\end{array}$ & $\begin{array}{l}-3.1961 \\
(-1.74)^{*}\end{array}$ & $\begin{array}{l}-1.5152 \\
(-1.23)\end{array}$ & $\begin{array}{l}-1.8629 \\
(-1.57)\end{array}$ & $\begin{array}{l}-2.5681 \\
(-1.96)^{*}\end{array}$ & $\begin{array}{l}-1.8285 \\
(-1.60)\end{array}$ \\
\hline$R-s q$ & .1281 & .1340 & .3370 & .2822 & .2083 & .2659 \\
\hline $\begin{array}{l}\text { Number of obser- } \\
\text { vations }\end{array}$ & 242 & 452 & 750 & 960 & 725 & 1202 \\
\hline
\end{tabular}

All variables are used in their first differences. $t$-statistics in parenthesis. ${ }^{*}{ }^{* *},{ }^{* * *}$ indicate significance at $10 \%, 5 \%, 1 \%$, respectively. The estimates for the constants are not shown

balances. Higher inflation rates (CPI) on some group of countries (Table 4) decreases the current account deficits. When CPI gets higher, it is considered that economic stability is getting worse so this causes less capital flow to these countries and ends up less current account deficits. For industrial countries when the inflation rate increases, it seems consumption increases as well, and current account deficits get higher.

Voice and accountability, political stability and absence of violence, political constraint variables are tested individually and identified as institutional determinants of current account balances in a study for the first time. Political risks are found to have overall negative and statistically significant relationships with current account balances for high income and full sample except for Africa and industrial countries groups (Table 5). When political risks are less for these group of countries more capital flows, and current account deficits increase.

Political stability is found to have overall negative and statistically significant relationships with current account balances for the full sample, full sample except for industrial countries and full sample except for Africa and industrial countries groups (Table 6). When political stability is higher for these group of countries more capital flows, and current account deficits increase. For the full sample except for Africa and industrial countries group, legal system and property rights, voice and accountability are found to be the determinants of current account balance (Table 7). Trustworthy legal system and 
Table 6 Current account balance: institutional quality—political stability (1996-2013)

\begin{tabular}{|c|c|c|c|c|c|c|}
\hline & Industrial & High income & Developing & $\begin{array}{l}\text { Full sample - } \\
\text { Industrial }\end{array}$ & $\begin{array}{l}\text { Full sample - } \\
\text { Africa } \\
\text { and Industrial }\end{array}$ & $\begin{array}{l}\text { Full } \\
\text { sample }\end{array}$ \\
\hline \multirow[t]{2}{*}{ GDP } & .1797 & -.0296 & .1082 & .01332 & -.0337 & .0393 \\
\hline & $(2.29)^{* *}$ & $(-.60)$ & $(1.31)$ & (.19) & $(-.39)$ & $(.64)$ \\
\hline \multirow[t]{2}{*}{ Fiscal balance } & -.0623 & .1841 & .2529 & .2674 & .1454 & .2532 \\
\hline & $(-.36)$ & $(1.48)$ & $(1.85)^{*}$ & $(2.12)^{* *}$ & (1.33) & $(2.28)^{* *}$ \\
\hline \multirow[t]{2}{*}{ Terms of trade } & .0372 & .0028 & .0947 & .0650 & .0573 & .0605 \\
\hline & $(1.04)$ & $(.16)$ & $(4.39)^{* * *}$ & $(3.36)^{* * *}$ & $(2.94)^{* * *}$ & $(3.34)^{* * *}$ \\
\hline \multirow{2}{*}{$\begin{array}{l}\text { Real effective } \\
\text { exchange rate }\end{array}$} & -.0552 & -.0398 & -.1344 & -.1074 & -.1091 & -.1035 \\
\hline & $(-1.12)$ & $(-1.04)$ & $(-4.32)^{* * *}$ & $(-3.35)^{* * *}$ & $(-2.71)^{* * *}$ & $(-3.78)^{* * *}$ \\
\hline \multirow[t]{2}{*}{ Trade openness } & -.0729 & -.0113 & -.2254 & -.1006 & -.0677 & -.0951 \\
\hline & $(-1.35)$ & $(-.50)$ & $(-4.47)^{* * *}$ & $(-2.76)^{* * *}$ & $(-1.82)^{*}$ & $(-2.91)^{* * *}$ \\
\hline \multirow[t]{2}{*}{ Relative income } & -29.4922 & -7.6128 & -63.9564 & 18.5286 & 16.7302 & -.2062 \\
\hline & $(-2.01)^{* *}$ & $(-.82)$ & $(-.60)$ & $(1.26)$ & $(1.29)$ & $(-.02)$ \\
\hline \multirow{2}{*}{$\begin{array}{c}\text { Average net crude } \\
\text { oil export/GDP }\end{array}$} & -.0303 & .5128 & .5694 & .6172 & .8676 & .6048 \\
\hline & $(-.08)$ & $(2.00)^{* *}$ & $(3.57)^{* * *}$ & $(3.88)^{* * *}$ & $(3.00)^{* * *}$ & $(3.92)^{* * *}$ \\
\hline \multirow{2}{*}{$\begin{array}{l}\text { Total private } \\
\text { credit/GDP }\end{array}$} & -.0444 & -.0265 & -.0918 & -.0285 & -.0262 & -.0327 \\
\hline & $(-3.27)^{* * *}$ & $(-3.67)^{* * *}$ & $(-2.61)^{* *}$ & $(-2.44)^{* *}$ & $(-2.87)^{* * *}$ & $(-2.67)^{* * *}$ \\
\hline \multirow{2}{*}{$\begin{array}{l}\text { Political stability } \\
\text { and absence of } \\
\text { violence }\end{array}$} & .2175 & -.3655 & -1.3520 & -1.3147 & -2.0465 & -1.1350 \\
\hline & $(.29)$ & $(-.48)$ & $(-1.44)$ & $(-1.67)^{*}$ & $(-2.11)^{* *}$ & $(-1.72)^{*}$ \\
\hline$R-s q$ & .1641 & .0953 & .3621 & .2595 & .2100 & .2380 \\
\hline $\begin{array}{l}\text { Number of obser- } \\
\text { vations }\end{array}$ & 226 & 399 & 447 & 619 & 485 & 845 \\
\hline
\end{tabular}

All variables are used in their first differences. $t$-statistics in parenthesis. ${ }^{*},{ }^{* *},{ }^{* * *}$ indicate significance at $10 \%, 5 \%, 1 \%$, respectively. The estimates for the constants are not shown

secure property rights encourage capital flows to these countries which causes higher current account deficits.

Cheung et al. (2013) find a statistically significant relationship only with regularity quality and current account balance with a negative sign for the full sample. They weren't able to find any relationship with political risks, voice and accountability, political stability, government effectiveness, rule of law, control of corruption and political constraint variables. Chinn and Ito (2007) find a statistically significant relationship with Legal variable which is combined of law and order, corruption and bureaucracy quality. Gruber and Kamin. (2005) find statistically significant relationship only with regulatory quality and rule of law for some of the country groups. They were not able to find any relationship individually with voice and accountability, political stability, government effectiveness and controls of corruption.

For the USA, UK, Japan, Germany and Italy political stability equation for highincome countries is used. These counties are selected because of their relatively large contribution to global imbalances. The variables identified can explain reasonably 
Table 7 Current account balance: all institutional quality determinants for full sample except Africa and industrial countries

\begin{tabular}{|c|c|c|c|c|}
\hline & $\begin{array}{l}\text { Full sample - } \\
\text { Africa } \\
\text { and industrial }\end{array}$ & $\begin{array}{l}\text { Full sample - } \\
\text { Africa } \\
\text { and industrial }\end{array}$ & $\begin{array}{l}\text { Full sample - } \\
\text { Africa } \\
\text { and industrial }\end{array}$ & $\begin{array}{l}\text { Full sample - } \\
\text { Africa } \\
\text { and industrial }\end{array}$ \\
\hline GDP & $\begin{array}{l}-.1407 \\
(-3.60)^{* * *}\end{array}$ & $\begin{array}{l}-.1150 \\
(-1.63)\end{array}$ & $\begin{array}{l}-.0337 \\
(-.39)\end{array}$ & $\begin{array}{l}-.0354 \\
(-.42)\end{array}$ \\
\hline Fiscal balance & $\begin{array}{l}.1005 \\
(.88)\end{array}$ & $\begin{array}{l}.1247 \\
(1.34)\end{array}$ & $\begin{array}{l}.1454 \\
(1.33)\end{array}$ & $\begin{array}{l}.1332 \\
(1.24)\end{array}$ \\
\hline Terms of trade & $\begin{array}{l}.0294 \\
(1.96)^{* *}\end{array}$ & $\begin{array}{l}.0615 \\
(2.76)^{* * *}\end{array}$ & $\begin{array}{l}.0573 \\
(2.94)^{* * *}\end{array}$ & $\begin{array}{l}.0558 \\
(2.84)^{* * *}\end{array}$ \\
\hline Real effective exchange rate & $\begin{array}{l}-.0777 \\
(-4.18)^{* * *}\end{array}$ & $\begin{array}{l}-.1065 \\
(-3.57)^{* * *}\end{array}$ & $\begin{array}{l}-.1091 \\
(-2.71)^{* * *}\end{array}$ & $\begin{array}{l}-.1109 \\
(-2.84)^{* * *}\end{array}$ \\
\hline Trade openness & $\begin{array}{l}-.0362 \\
(-1.70)^{*}\end{array}$ & $\begin{array}{l}-.0682 \\
(-2.33)^{* *}\end{array}$ & $\begin{array}{l}-.0677 \\
(-1.82)^{*}\end{array}$ & $\begin{array}{l}-.0663 \\
(-1.85)^{*}\end{array}$ \\
\hline Relative income & $\begin{array}{l}7.9815 \\
(.62)\end{array}$ & $\begin{array}{l}-6.1277 \\
(-.33)\end{array}$ & $\begin{array}{l}16.7302 \\
(1.29)\end{array}$ & $\begin{array}{l}14.1593 \\
(1.09)\end{array}$ \\
\hline $\begin{array}{l}\text { Average net crude oil export/ } \\
\text { GDP }\end{array}$ & $\begin{array}{l}.5975 \\
(2.59)^{* * *}\end{array}$ & $\begin{array}{l}.7978 \\
(3.41)^{* * *}\end{array}$ & $\begin{array}{l}.8676 \\
(3.00)^{* * *}\end{array}$ & $\begin{array}{l}.8906 \\
(3.17)^{* * *}\end{array}$ \\
\hline Total private credit/GDP & $\begin{array}{l}-.0230 \\
(-2.68)^{* * *}\end{array}$ & $\begin{array}{l}-.0209 \\
(-2.82)^{* * *}\end{array}$ & $\begin{array}{l}-.0262 \\
(-2.87)^{* * *}\end{array}$ & $\begin{array}{l}-.0273 \\
(-3.23)^{* * *}\end{array}$ \\
\hline $\begin{array}{l}\text { Political stability and the } \\
\text { absence of violence } \\
\text { 220132013) }\end{array}$ & & & $\begin{array}{l}-2.0465 \\
(-2.11)^{* *}\end{array}$ & \\
\hline (1996-2013) & & & & \\
\hline $\begin{array}{l}\text { Legal system and property } \\
\text { rights (1990-2013) }\end{array}$ & $\begin{array}{l}-.7381 \\
(-2.03)^{* *}\end{array}$ & & & \\
\hline Polcon V (1986-2013) & & $\begin{array}{l}-2.5681 \\
(-1.96)^{*}\end{array}$ & & \\
\hline $\begin{array}{l}\text { Voice and accountability } \\
\quad(1996-2013)\end{array}$ & & & & $\begin{array}{l}-5.0551 \\
(-2.08)^{* *}\end{array}$ \\
\hline$R-s q$ & .1573 & .2083 & .2100 & .2150 \\
\hline Number of observations & 500 & 725 & 485 & 485 \\
\hline
\end{tabular}

All variables are used in their first differences. $t$-statistics in parenthesis. ${ }^{*},{ }^{* *},{ }^{* *}$ indicate significance at $10 \%, 5 \%, 1 \%$, respectively. The estimates for the constants are not shown

well the direction of current account patterns for these countries: USA, UK, Germany, Japan, China, and Italy (Fig. 1).

Brazil, Chile, India and Turkey are selected because they are called fragile economies (Kynge and James 2014) with their large current account deficits (Fig. 3). To understand what is driving these results, it is helpful to decompose the contributions of the first differences of current account balances.

Figures show the time period between 2003 and 2012 because there is no missing annual data for the time period for these countries. This time period explains well the direction and the decomposition of the current account balances before and after the global financial crises. 


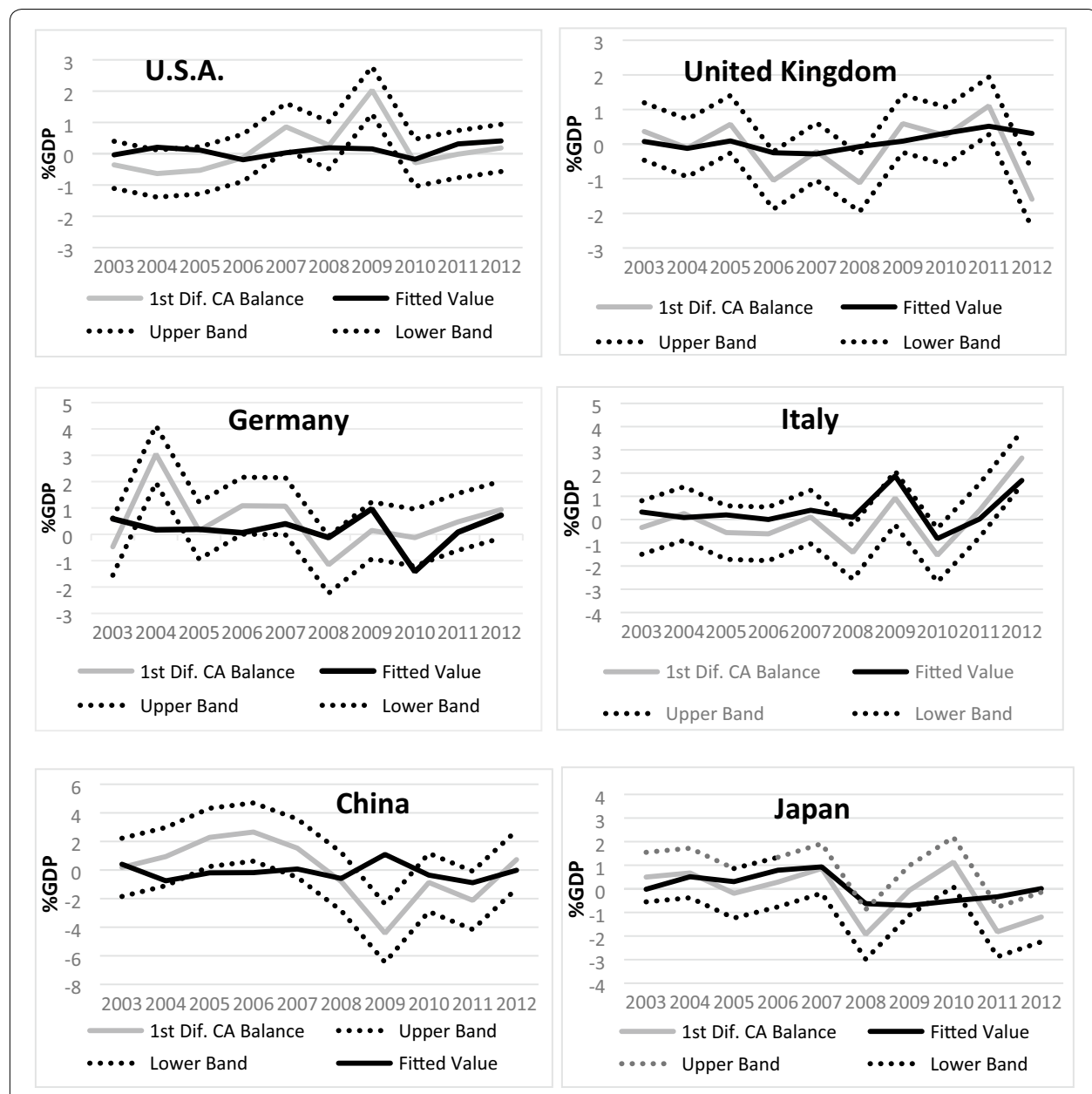

Fig. 1 Predicted first difference of current account balance with political stability and financial development

The USA, UK and Italy have run current account deficits between 2003 and 2012. For the USA, private credit appears to have contributed current account deficits between 2003 and 2007. This supports Ben Bernanke saying that global savings flow through the US because of financial and institutional quality. The advanced financial system in the USA supported capital flows from emerging economies with excess savings and underdeveloped financial markets. So private credit is the most important variable for the US to explain the current account balances.

The second important parameter appears to be crude oil export. That is why shale gas production is key to improve US current account deficits. It seems when US imports less crude oil it will have a big impact on current account deficits. Political stability also has an effect on the current account balance.

Another important variable for the US is the fiscal balance. Especially, between 2007 and 2010 fiscal deficits helped increasing current account deficits. Every year fiscal balance has a significant impact on current account balances (Fig. 2).

For the UK, same as US private credit is the most important parameter that explains current account deficits. Between 2003 and 2009 private credit has increased the current account deficit of the UK significantly. Fiscal balance is important between 2008 


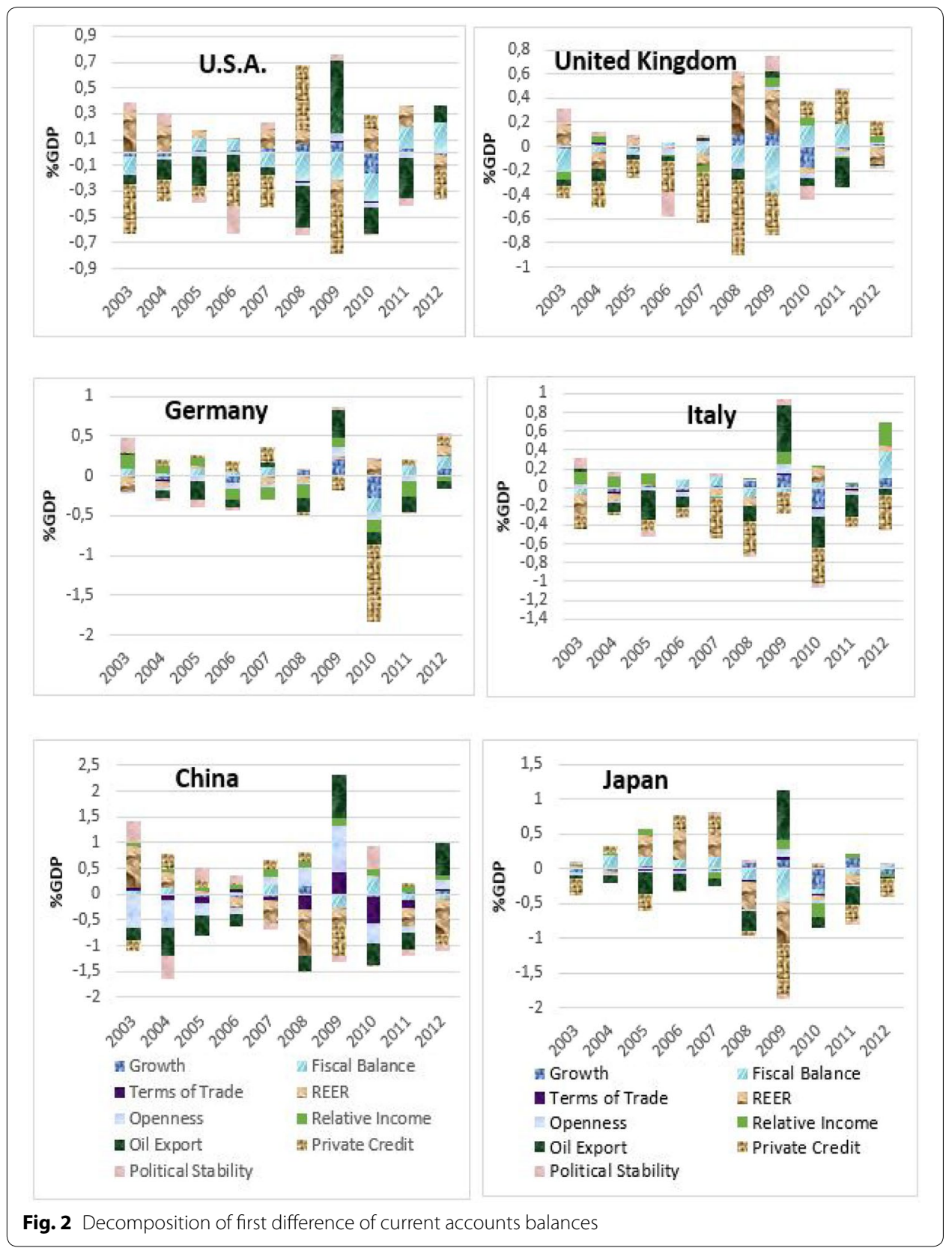

and 2011 for current account balances. Real effective exchange rate after the financial crisis 2008 and 2009 has a significant impact on reducing the current account deficit. Political stability has a limited impact on current account balances (Fig. 2).

For Italy, similar to USA and UK private credit is one of the most significant factors of current account deficits. It has a significant impact for 10 years on the current account deficit. Crude oil export is another key factor. Political stability has very limited effect (Fig. 2).

Germany, Japan and China have run current account surpluses between 2002 and 2013. For Germany, private credit has no significant impact on current accounts balance 


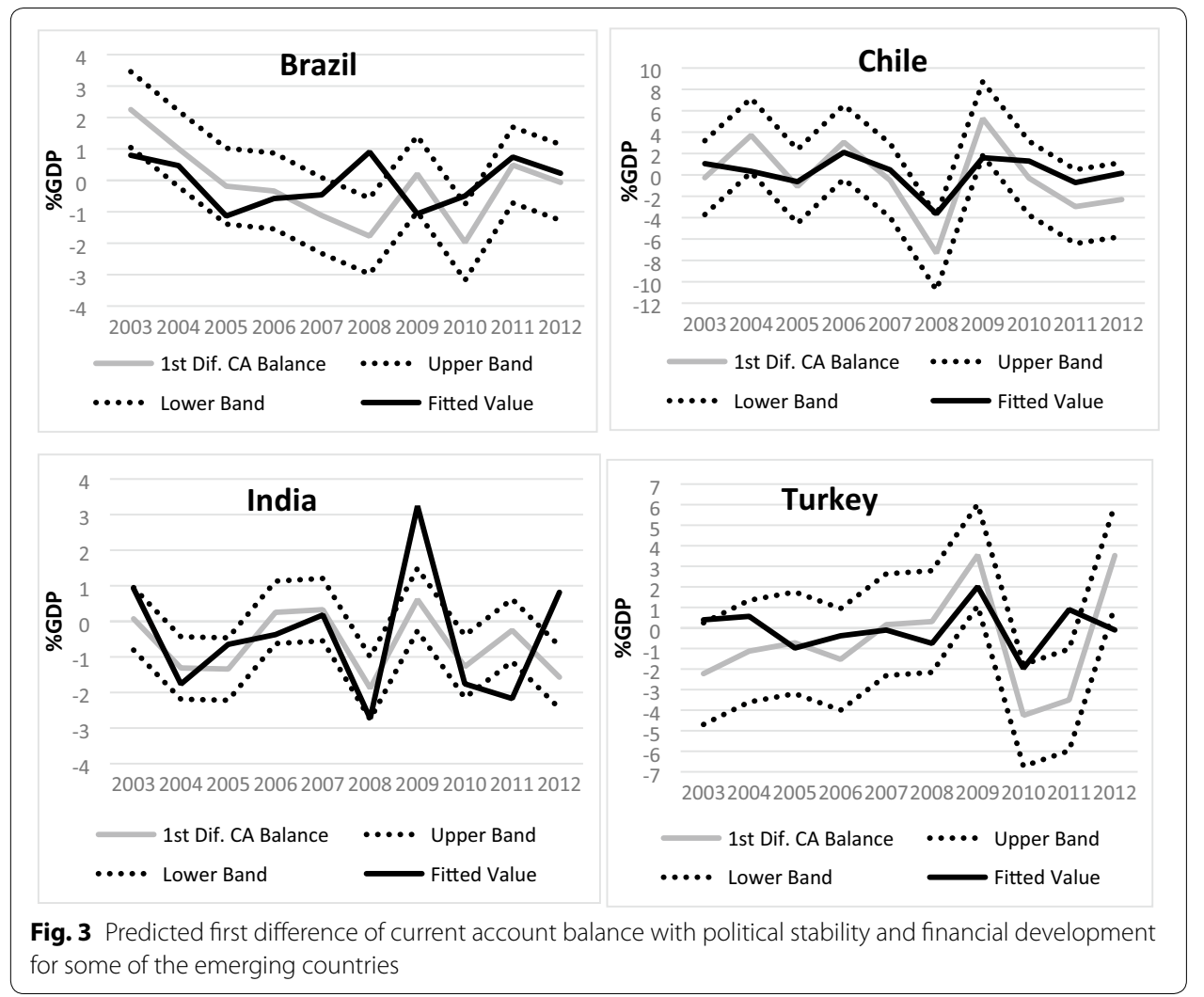

except 2010. Political stability has no significant effect either except 2003. Crude oil export is one of the important variables (Fig. 2).

For Japan, private credit is one of the key variables; the effect is less than the UK and USA. Crude oil is another important factor that has an impact every year. Except in 2009 it helps to decrease the current account surplus of Japan. Political stability nearly has no influence. Japan's current account surplus is also affected by the real effective exchange rate. It helped to increase the surplus between 2005 and 2007 and helped to decrease surpluses between 2008 and 2012 (Fig. 2).

Trade openness, crude oil export, real effective exchange rate are key variables for China's current accounts balance. Political stability also affects. Terms of trade between 2008 and 2011 have a significant role in the current accounts balance as well. Crude oil export decreases the surpluses except 2009 and 2012.

For China, Brazil, Chile, Turkey and India political stability equation for full sample except for Africa and Industrial countries is used. The variables identified can explain reasonably well the direction of current account patterns for these developing countries (Fig. 3). Brazil, India, Turkey, Chile are called fragile economies (Gayyn and Davies 2014) from time to time because of the current account deficits they have.

Brazil has 5 years of current account surpluses and 5 years of current account deficits. Two main factors have a significant impact on current accounts balances are the change in the real effective exchange rate and terms of trade. Private credit has limited effect. Political stability is one of the other important variables. Political stability affects 


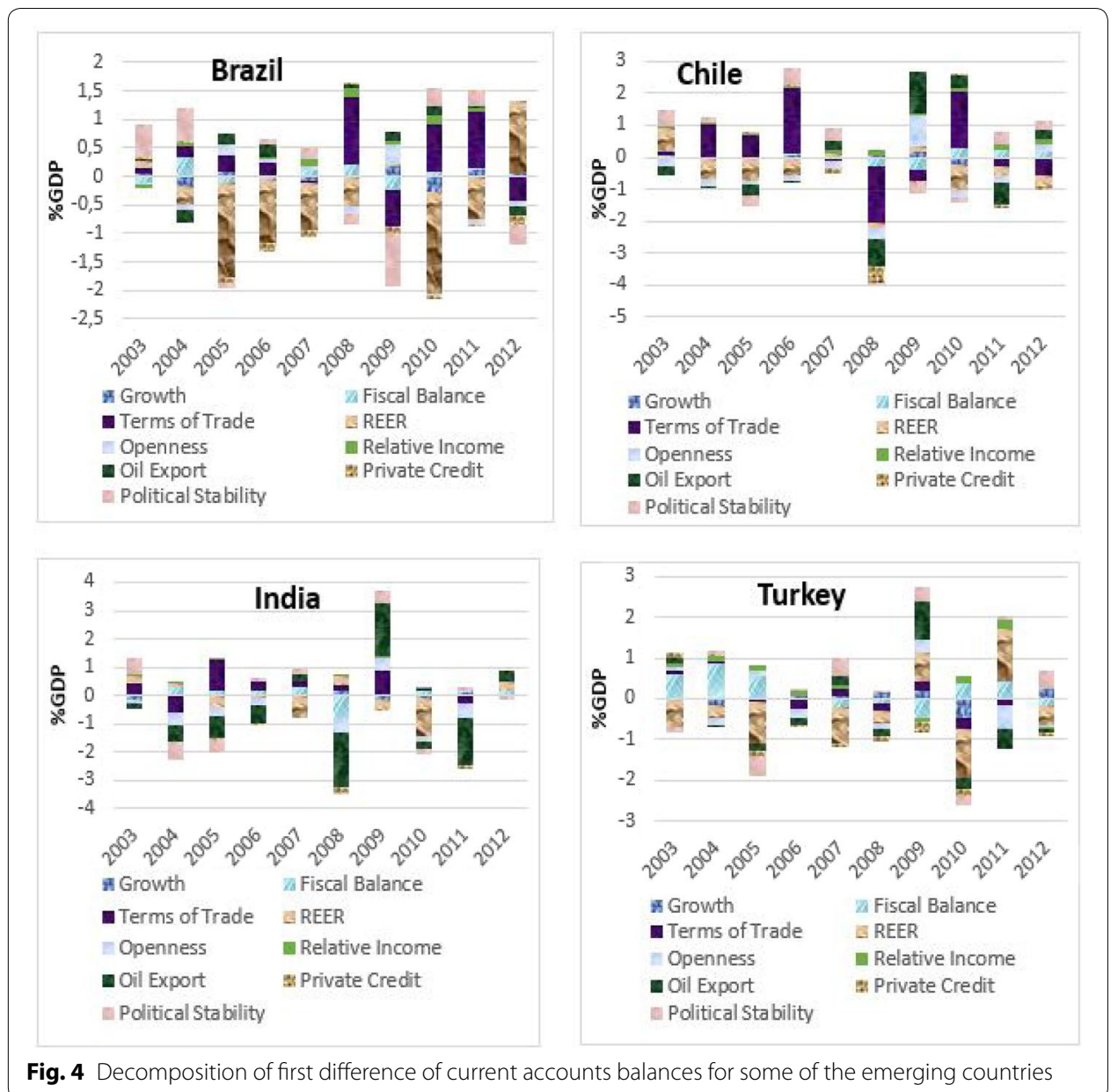

capital flows from outside the country. This capital flow has a positive or negative effect of financing the current account deficits. Except for a couple of years, the real effective exchange rate has a significant effect on increasing the current account deficits (Fig. 4).

Chile has 4 years of deficits and 6 years surpluses. Similar to Brazil, terms of trade and real exchange rate are two key variables. Crude oil export played an important role especially after 2006. Political stability is another key variable. Similar to Brazil affected by political stability, the amount of capital flows from outside of the country change. Again, current account balances change positive or negatively with the change of these main factors (Fig. 4). India has 8 years of current account deficits and 2 years of surpluses. Crude oil export, terms of trade, real effective exchange rate are the key parameters. Private credit nearly has no effect. Political stability is another key variable (Fig. 4).

Turkey has 10 years of current account deficits. Key deliverables are real effective exchange rate, crude oil export and fiscal balance. Terms of trade between 2006 and 2011 have increased the deficits. Private credit has also increased the deficits except for 3 years. Political stability also is another factor which affects the current account deficit. 
Similar to Chile and Brazil with the change of political stability, the amount of capital flows outside the country change. Real effective exchange rate changes are significant (Fig. 4).

The so-called fragile economies all have current account deficits (Morgan Stanley 2013). When political stability increases, more capital flows outside the country. This increment helps them easier to finance their current account deficits. The real effective exchange rate has a significant effect generally to widen the current account deficit for these countries. This can be explained as, with a high amount of financial capital flow outside the country, the local currency gets overvalued affected by relatively highinterest rates and current account deficits get larger. When political and macroeconomic stability, institutional quality gets worse emerging countries with high current account deficits and external debts may face difficulties to finance these deficits with financial capital flows. That is why they are called fragile economies in different sources. Political stability, terms of trade, real effective exchange rate are key variables for these countries (Fig. 4).

\section{Conclusions}

This paper investigates the fundamental macroeconomic, institutional and financial determinants of current accounts balance by using panel data analysis method. The analysis is carried out by using the data for the period between 1986 and 2013 (includes the time period after 2008 financial crisis which most of the other papers do not capture) of 97 developing and developed countries. We find that the determinants of current account balances can be related to the factors such as fiscal balance, growth, terms of trade, exchange rate, trade openness, stage of economic development, oil dependency, financial market development, macroeconomic stability and institutional quality.

A rise in growth rate, real effective exchange rate, fiscal deficit, trade openness, institutional quality, financial market development and stage of development generates larger current account deficits. A rise in terms of trade, inflation rate (representing macroeconomic stability), and crude oil export reduce the current account deficits. For industrial countries, macroeconomic stability and growth have an opposite effect on current account balances compared with other groups. The legal system and property rights, voice and accountability, political stability and absence of violence, political risks are identified as the institutional determinants of current account balances.

In our study, for the first time private credit has a statistically significant relationship with current account balances for all six country groups with a negative sign. Moreover, results support the hypothesis (Bernanke 2005) that the pattern of global imbalances in the 2000s that reflects in part the flow of financial capital from some of the emerging economies with under-developed institutions and financial markets and excess savings towards economies perceived to have more efficient institutions and financial systems like US and UK. Financial development is especially key for USA, UK, Italy and Japan's (less contribution compared with the US and UK) current account balances. 
Voice and accountability, political stability and absence of violence, political constraint variables are tested individually and identified as institutional determinants of current account balances in a study for the first time. For Germany, political stability and financial development are less important. Institutional quality especially political stability seems to be more important than financial development for developing countries like Brazil, Turkey, Chile, and India. The real effective exchange rate also has a significant impact on these developing countries' current account balances. Crude oil export also key variable especially for USA, UK, Japan, China, Turkey, and India to widen the deficits or decrease the surpluses. Terms of trade seem to be an important factor for these developing countries.

None of the studies considers macroeconomic stability as one of the determinants of the current account balances. Macroeconomic stability in the form of low inflation seems to be another key factor for current account balances and the flow of financial capital. It seems especially important for developing countries. There is a positive relationship between inflation rate and current account balances. It is insignificant for highincome countries.

Although some legal system related variables were found as determinants of current account balances in other studies, legal system and property rights variable is found as one of the determinants of current account balances first time in this study. The legal system and property rights and also voice and accountability are other key factors for full sample except for industrial and African countries, in other words for most of the developing countries. Political stability, trustworthy legal system and secured property rights encourage financial flows to these developing countries which increase the current account deficits of these countries.

Acknowledgements

Not applicable.

Authors' contributions

$M C$ and YA agreed on the content of the study. MC collected all the data for analysis. MC and YA agreed on the methodology. MC completed the analysis based on agreed steps. Results and conclusions are discussed and written together. Both authors read and approved the final manuscript.

\section{Funding}

No funding is used.

Availability of data and materials

The datasets used and analysed during the current study are available from the corresponding author on request.

Competing interests

The authors declare that they have no competing interests.

Author details

${ }^{1}$ Department of Economics, Istanbul University, Istanbul PC 34452, Turkey. ${ }^{2}$ Ford Otomotiv Sanayi A.Ş., Istanbul PC 34885 , Turkey.

Received: 27 August 2019 Revised: 10 May 2020 Accepted: 18 July 2020

Published online: 31 July 2020

\section{References}

Alfaro L, Sebnem KO, Vadyn V (2005) Why doesn't Capital Flow from Rich to Poor Countries? An Empirical Investigation. In: NBER Working Paper No: 11901

Arellano M (1987) Computing robust standard errors for within-groups estimators. Oxford Bull Econ Stat 49(4):431-434

Aristovnik A (2006) The determinants and excessiveness of current account deficits in Eastern Europe and the Former Soviet Union. William Davidson Institute, New York, p 827 
Bernanke B (2005) The global saving glut and the U.S. Current Account Deficit. In: Remarks by Governor Ben S. Bernanke, at the Homer Jones Lecture, St. Louis, Missouri

Bruegel The Brussels-based Economic Think Tank (2016) The Effective Real Exchange Rate Dataset. http://brueg el.org/publications/datasets/real-effective-exchange-rates-for-178-countries-a-new-database/

Calderon C, Alberto C, Norman L (2002) Determination of Current Account Deficits in Developing Countries. In: World Bank Policy Research Working Paper, No. 2398

Cheung C, Furceri D, Rusticelli E (2013) Structural and cyclical factors behind current account balances. Rev Int Econ 21:923-944

Chinn M, Ito H (2007) Current account balances, financial development and institutions: assaying the World Saving Glut. J Int Money Finance 26(4):546-569

Chinn M, Prasad E (2003) Medium-term determinants of current accounts in industrial and developing countries: an empirical exploration. J Int Econ 59:47-76

Choi I (2001) Unit root tests for panel data. Journal of International Money and Finance 20:249-272

IMF World Economic Outlook Database. Current Accounts Balance Dataset, Inflation Dataset. https://www.imf.org/ external/pubs/ft/weo/2016/01/weodata/index.aspx/. Accessed 15 Jul 2016

Debelle G, Hamid F (1996) What determines the current account. IMF Research Department, WP/96/58

Eicker $F(1967)$. Limit theorems for regression with unequal and dependent errors. In: Proceedings of the fifth berkeley symposium on mathematical statistics and probability, 59-82. Berkeley, University of California Press

Fraser Institute (2017) Economic Freedom Index Dataset. https://www.fraserinstitute.org/. Accessed 11 Jul 2016

Freund CL (2000) Current Account Adjustment in Industrialized Countries. Board of Governors of the Federal Reserve System International Finance Discussion Papers, Number 692

Froot KA (1989) Consistent covariance matrix estimation with cross-sectional dependence and heteroskedasticity in Financial Data. J Fin Quant Anal 24:333-355

Gayyn D(2014). The EM's fragile eight must save themselves". Financial Times. http://blogs.ft.com/gavyndavies. Accessed 11 Feb 2015

Gruber J, Kamin S (2009) Do differences in financial development explain the global pattern of current account imbalances. Rev Int Econ 17(4):667-688

Gruber J, Steven K (2005) Explaining the Global Pattern of Current Account Imbalances. Board of Governors of the Federal Reserve System International Finance Discussion Papers, Number 846

Harberger AC (1950) Currency depreciation, income, and the balance of trade. J Polit Econ 58(1):47-60

Hausman J (1978) Specification tests in econometrics. Econometrica 46:1251-1271

Hoyos R, Sarafidis V (2006) Testing for cross-sectional dependence in panel-data models. The Stata Journal 6(4):482-496

Huber PJ (1967) The behavior of maximum likelihood estimates under non-standard conditions. In: Proceedings of the Fifth Berkeley Symposium on Mathematical Statistics and Probability, 1, 221-223. University of California Press, Berkeley

Ju J, Wei S-J (2006) A Solution to Two Paradoxes of International Capital Flows. NBER Working Paper 12668

Kennedy M, Slok T (2005) Structural policy reforms and external imbalances. In: OECD Economics Department Working Papers No. 415

Kynge J (2014) Fragile Five falls short as Tapering leaves more exposed. Financial Times. http://www.ft.com. Accessed 11 Feb 2015

Laursen S, Metzler LA (1950) Flexible exchange rates and the theory of employment. Rev Econ Stat 32(4):281

Legg A, Nalini P, Tim R (2011) Global imbalances and the global saving glut- a panel data assessment. In: Economic Research Department Reserve Bank of Australia, Research Discussion Paper 2007-11

Lucas RE (1988) On the mechanism of economic development. J Monet Econ 22:3-22

Morgan Stanley Global Emerging Markets Equity Team (2013) Tales from the Emerging World. Morgan Stanley. https ://www.morganstanley.com. Accessed 03 May 2015

Odedokun Matthew (2003) The 'Pull' and 'Push' Factors in North-South Private Capital Flows Conceptual Issues and Empirical Estimates. WIDER Discussion Paper, New York

OECD (2016) Fiscal Balance Dataset. https://data.oecd.org/. Accessed 15 Jun 2016

Pesaran MH (2004) General Diagnostic Tests for Cross Section Dependence in Panels. CESifo Working Paper, vol 1229, pp $1-40$

Pesaran MH (2007) A simple panel unit root test in the presence of cross-section dependence. J Appl Econ 22(2):265-312

Rogers WH (1993) Regression standard errors in clustered samples. Stata Tech Bulletin issue 13: 19-23

The U.S. Energy Information Administration (EIA). World Crude Oil Export and Import Dataset. https://www.eia.gov/. Accessed 15 Jul 2016

The Wharton University of Pennsylvania. The Political Constraint Index (POLCON) Dataset. https://mgmt.whart on.upenn.edu/faculty/heniszpolcon/polcondataset/. Accessed 11 Jul 2016

White H (1980) A heteroskedasticity-consistent covariance matrix estimator and a direct test for heteroskedasticity. Econometrica 48:817-838

Wooldridge JM (2002) Econometric analysis of cross section and panel data. MIT Press, Cambridge

World Bank (2016a) Macro Economical Variables Dataset. http://data.worldbank.org. Accessed 16 Jul 2016

World Bank (2016b) The World Governance Indicators Dataset. http://data.worldbank.org/data-catalog/worldwide-gover nance-indicators/. Accessed 11 Jul 2016

\section{Publisher's Note}

Springer Nature remains neutral with regard to jurisdictional claims in published maps and institutional affiliations. 